\title{
Preparation of recombinant proteins in milk to improve human and animal health
}

\author{
Eric SOLER ${ }^{\mathrm{a}}$, Dominique THÉPOT ${ }^{\mathrm{b}}$, Sylvie RIVAL-GERVIER ${ }^{\mathrm{b}}$, \\ Geneviève JOLIVET $^{\mathrm{b}}$, Louis-Marie HOUDEBINE ${ }^{\mathrm{b} *}$ \\ ${ }^{a}$ BioProtein Technologies 63, Domaine de Vilvert, 78350, Jouy-en-Josas, France \\ ${ }^{b}$ UMR Biologie du Développement et Reproduction, Institut National de la Recherche Agronomique, \\ 78352 Jouy-en-Josas, France
}

\begin{abstract}
Milk is a very abundant source of proteins for animal and human consumption. Milk composition can be modified using transgenesis, including exogenous gene addition and endogenous gene inactivation. The study of milk protein genes has provided researchers with regulatory regions capable of efficiently and specifically driving the expression of foreign genes in milk. The projects underway are aimed at modifying milk composition, improving its nutritional value, reducing mammary infections, providing consumers with antipathogen proteins and preparing purified recombinant proteins for pharmaceutical use. The present paper summarises the current progress in this field.
\end{abstract}

milk / recombinant proteins / animal and human health

\section{INTRODUCTION}

Milk is essential for new born mammals and animal milk has been used as food for centuries by many human communities. Genetic selection has greatly improved milk production of domestic animals. The major impact of selection so far concerns the amount of milk rather than its composition. The major milk compounds are proteins, lipids and lactose. Some of these molecules may have a negative impact on human health. This is the case of lactose which cannot be digested by a majority of adult human consumers. Several proteins, $\beta$-lactoglobulin and to a lower degree caseins, are allergenic for human consumers. Milk lipids may contribute to the development of cardiovascular diseases in humans. Moreover, it should be added

\footnotetext{
* Corresponding author:

louis.houdebine@jouy.inra.fr
}

that milk is a very abundant fluid that can be collected easily and can be a vehicle for various molecules and mainly proteins which can be synthesised by the mammary gland.

The knowledge of gene structure offers additional possibilities for farm animal selection. The best alleles of the major milk protein genes can now be selected using genetic markers. This approach is being more and more used. Yet, it remains that a number of modifications of milk composition can be obtained only via transgenesis. The proof of the concept was given more than one decade ago. The use of transgenesis for the improvement milk composition remains limited by technical problems in generating transgenic animals and in obtaining a reliable transgene expression. This review describes the recent technical progress in this field and summarises the different projects underway to improve 
milk composition or to use milk as a source of therapeutical proteins.

\section{GENE TRANSFER TO FARM ANIMALS}

Gene transfer is a major limitation in the use of transgenic farm animals [1]. The classical DNA microinjection into the embryo is very poorly efficient in ruminants and totally inefficient in birds. The cloning technique by nuclear transfer, although not highly efficient, greatly improved gene transfer into ruminants. With cloning, the yield of transgenic animals is higher, the animals are not mosaic for the transgene and the integration site as well as the integrity of the transgene can be examined in transfected cells used for gene transfer. Interestingly, the cloning technique, although laborious, allows gene replacement by homologous recombination. In a recent work, it was shown that the two alleles of two genes can be knocked out in the same cow using the cloning technique [2]. This shows that milk protein genes can be introduced in chosen sites and that milk protein genes can be replaced by any gene using homologous recombination.

The generation of chimeric animals using pluripotent ES (embryonic stem) cells has proven highly useful to knock out genes in mice. More than 3000 genes have been knocked out or knocked in this species. The same appears impossible in other species including birds [3]. It was shown that the repeated failure was due to the fact that no genuine pluripotent ES cell lines can be obtained from animals other than two breeds of mice. Interestingly, recent works have shown that stable lines of chicken and quail PGC (primordial germ) cells can be established. These cells keep their pluripotency and they participate in the generation of chimeric transgenic birds which transmit their transgenesis to progeny $[4,5]$.
Transposons and mainly lentiviral vectors have proven to be efficient tools to transfer genes into a broad variety of cells and animals. This is particularly impressive for ruminants since up to $80 \%$ of the infected embryos can give birth to transgenic animals $[6,7]$. The lentiviral vectors also show some limitations. A limited size of foreign DNA $(<10 \mathrm{~kb})$ can be introduced in the vectors, the transgenic animals often harbour independent integrated transgenes and the LTR of the vectors can interfere with the transgene promoters. Yet, this tool has considerably simplified transgenesis in ruminants.

\section{EXPRESSION VECTORS FOR TRANSGENE EXPRESSION}

The second problem experimenters have to face with transgenesis is the expression of transgenes which is classically ill-controlled. This is clearly due to the fact that only a part of the gene regulatory elements is known. This leads experimenters to associate non-compatible elements when they construct their genes. A few general rules have emerged to enhance the chance of obtaining a reliable expression of transgenes [8]. The addition of insulators is one of the most efficient ways to prevent transgene silencing $[8,9]$. Other isolated known elements (introns, enhancers, mRNA stabilisers, translation stimulators) can be added to the gene constructs [8]. A trend consists in using long genomic DNA fragments which contain most if not all the regulatory elements of milk protein genes. Indeed, it is acknowledged that elements located $50-200 \mathrm{~kb}$ upstream of a gene transcription start site can associate with the promoter to form a fully active transcription complex thanks to a looping mechanism [10]. Three long genomic DNA regions containing a milk protein are presently being used to express foreign genes. One is the pig WAP 
(whey acid protein) gene [11], another is the human $\alpha$-lactalbumin gene [12] and the third is the human lactoferrin gene [13]. These long genomic DNA fragments can harbour foreign cDNA or genes. The long genomic DNA fragments harbouring the foreign genes of interest can be cloned in BAC (bacterial artificial chromosomes) or YAC (yeast artificial chromosomes) and introduced in embryos by microinjection [11] or in cells further used to generate transgenic animals.

Gene knock out using homologous recombination remains a difficult task in farm animals and is possible only by using the cloning technique. This technique also offers limited flexibility since it is generally applied in early embryos and is irreversible. A possible alternative consists of using interfering RNA (RNAi) or microRNA (miRNA). These short double strand RNA induce the specific degradation or translation inhibition of the targeted mRNA [14].

Rules have been defined to design efficient RNAi [15] and miRNA [16]. Specific vectors allowing the synthesis of RNAi remain to be found although lentiviral vectors have proven to be an acceptable tool to reach this goal. However, ideally the synthesis of RNAi or miRNA should be possible using highly versatile promoters of genes transcribed by RNA polymerase II. This should be the case for RNAi and this is already a reality for miRNA which are naturally synthesised by RNA polymerase II. Gene expression can thus be counteracted specifically in the mammary gland using conventional vectors containing the promoter of a milk protein gene and a region coding for an miRNA.

\section{IMPROVEMENT OF MILK QUALITY}

Although milk is an excellent natural food, improvement of its production has been performed for centuries and it is pursued with different aims. Enhancing total milk production has been achieved by genetic selection and by optimising lactating female alimentation. Modifying milk composition may also be obtained to some degree by using the same techniques. Genetic engineering including transgenesis offers unprecedented means to improve milk quality. Modification of milk composition may be carried out for different reasons. It may be useful to remove allergenic proteins and to reduce lactose concentration. Some alleles of milk protein genes may be added to improve curd quality or to increase total milk nutritional value. Milk may also be a carrier to provide consumers with anti-pathogen molecules or with high quality lipids. Milk is also a possible source of pharmaceutical proteins. All these domains are currently being investigated. The projects underway are depicted below.

Transgenic pigs secreting their milk bovine $\alpha$-lactalbumin or pig IGF1 produce more milk products. This allows a higher survival of piglets. The transgenes do not alter animal health and these animals appear of real economical interest [17].

Transgenic cows overexpressing the bovine $\kappa$-casein gene have milk with lower size casein micelles. This is expected to stabilise micelles and to favour cheese preparation [18]. Unexpectedly, this milk is slightly yellow coloured and it contains lower amounts of $\beta$-casein [19]. The economical advantage of this milk remains to be proven.

Transgenic mice expressing anti-sense RNA directed against $\alpha$-lactalbumin mRNA have lower lactose concentration [20]. Similarly, transgenic mice secreting a lactase in their milk have less lactose [21]. It is not certain that these sophisticated approaches can compete with the conventional addition of exogenous lactases to milk. 
Inactivation of the $\beta$-lactoglobulin gene has been achieved in cows by homologous recombination in fibroblasts followed by cloning [13]. The homozygous animals bearing this mutation are expected to be less allergenic since $\beta$-lactobulin is one of the major milk allergens.

Milk lipid composition can be modified by expressing a stearoyl-CoA desaturase in the goat mammary gland [22]. Transgenic mice expressing $C$. elegans $\Delta$ - and $\Omega-3$ desaturase genes in their mammary gland secrete milk enriched in linoleic acid [23]. These two approaches support the idea that milk containing lipids preventing cardiovascular diseases will be some day available for consumers.

Several years ago, sheep secreting a mutated human $\alpha$-lactalbumin devoid of phenylalanine in their milk were generated by Pharmaceutical Proteins Limited. This purified protein could be a valuable source of aminoacids for patients suffering from phenylketone urea.

\section{RESISTANCE TO DISEASES}

Mammary gland infection is one of the major problems of lactating ruminants. However, contamination of milk and derived products by bacteria must be strictly controlled to prevent gastroenteritis diseases in consumers. Independently, consumers may be contaminated by various pathogens inducing gastroenteritis. Several proteins secreted in milk could participate in solving these problems.

Transgenic mice secreting a recombinant monoclonal antibody directed against coronavirus or virus induced encephalitis were obtained several years ago. Pups nourished with this milk were protected against infection by the viruses [24,25]. This suggests that various milks containing recombinant monoclonal antibodies might protect consumers against some infectious diseases and particularly gastroenteritis.
Cows secreting a bacterial protein, lysostaphin, having a strong antibacterial activity have been obtained. These animals have been proven to be highly resistant to mammary infection by Staphylococcus aureus [26]. The milk from these animals is also more resistant to a spontaneous infection by environment bacteria. It remains to be demonstrated whether this approach is acceptable for human consumers. It is not known for example whether lysostaphin would alter the consumer's intestinal flora.

Similarly, goats and cows secrete human lysozyme [27] or human lactoferrin in their milk $[13,28]$. These two proteins have a broad antibacterial activity. They might contribute to reduce the frequency of mastitis, to delay corruption of milk and products containing milk such as pastries. Animal and human consumers might also be protected against infection of their digestive tracts.

\section{PRODUCTION OF PHARMACEUTICAL PROTEINS IN MILK}

Proteins started being used as pharmaceuticals only recently by human communities. Plant extracts traditionally used as the source of therapeutical molecules have little chance to act through protein action. Indeed proteins present in plant extracts are probably inactivated during preparation and degraded when administered by the oral route.

Insulin extracted from the pig pancreas was the first protein used at a large scale by patients suffering from diabetes. In the early 1980's, recombinant human insulin started being prepared and used from bacteria expressing the corresponding cDNA. This has provided patients with a human protein of high quality. Human growth hormone was prepared soon after using the same approach. This made it possible to use a protein, no longer contaminated by 
prions. The preparation of bovine growth hormone provided farmers with enough quantities of the protein to stimulate milk secretion in ruminants.

It soon appeared that a limited number of therapeutical proteins can be prepared from recombinant bacteria. This is due to the fact that some proteins are lethal for the bacteria. Others form aggregate inclusion bodies rendering their purification difficult. Moreover, bacteria are unable to proceed efficiently to a number of posttranslational modifications of proteins such as folding, association of subunits, glycosylation and phosphorylation. Monoclonal antibodies can thus not be prepared from bacteria [29].

Yeast often produces limited amounts of recombinant proteins which are also not postranscriptionally modified in an appropriate manner. Interestingly, recent studies established recombinant yeast lines capable of glycosylating proteins in a manner similar to animal cells [30].

Pluricellular organisms, plants and animals are the best candidates for producing very large amounts of well-formed therapeutical proteins at a low cost. The idea was formulated for the first time in 1982 after the birth of giant transgenic mice harbouring exogenous growth hormone genes. Up to $10 \mu \mathrm{g} . \mathrm{mL}^{-1}$ or even more of human growth hormone was found in the blood of some mice. The blood of transgenic animals thus appeared as a possible source of recombinant proteins. This was confirmed by the generation of transgenic rabbits expressing human $\alpha$-antitrypsin in their blood at a concentration of $1 \mathrm{mg} \cdot \mathrm{mL}^{-1}$ [31]. It soon appeared that most proteins of interest have a short life and do not accumulate in the blood. However, the recombinant proteins may interfere with the physiology of the animals and it may be uneasy to purify them from blood.

In 1985, the demonstration that the generation of transgenic mammals using DNA microinjection in embryos is possible not only in mice but also in sheep, pigs and rabbits, opened new avenues. The idea to use milk as a source of recombinant proteins was formulated in 1986 and the demonstration was given in 1987 with the preparation of ovine $\beta$-lactoglobulin and human t-plasminogen activator in mouse milk.

Milk is presently the most mature transgenic system for the production of recombinant pharmaceutical proteins [32]. About 100 proteins have been prepared in mouse milk experimentally. One of them, human antithrombin III prepared in goat milk [37] has been approved by EMEA to be put on the market. Human protein $\mathrm{C}$ inhibitor prepared in rabbit milk is in phase III of clinical studies [37]. Other proteins such as recombinant rotaviral proteins prepared in rabbit milk [34,35] could become a safe and efficient vaccine for humans and farm animals.

A few milk protein gene promoters are being used to drive expression of genes coding for pharmaceutical proteins in milk: ruminant $\alpha$ s1- and $\beta$-casein, mouse and rabbit WAP, ovine $\beta$-lactoglobulin, human and goat $\alpha$-lactalbumin and more recently human lactoferrin [13]. Expression vectors are greatly improved by the use of insulators [9] and long DNA fragments ([11]; Soler et al., unpublished data).

A few species are being used to produce recombinant proteins in milk: rabbits, sheep, goats, pigs and cows. Each of these species offers advantages and drawbacks. The ruminants are easily milked but the generation of the transgenic founders requires cloning and they reproduce relatively slowly. Transgenic rabbits and also pigs can be obtained with good efficiency using DNA microinjection and they are highly prolific. Rabbits appear as the most flexible and the cheapest species but are too small for very large production of proteins. Rabbit and pig milking can be achieved with no particular difficulty using adapted machines. 
Rabbits and pigs appeared more able than ruminants to perform some posttranslational modifications as judged by the examination of a few proteins such as human protein $C$ [36] and human protein $\mathrm{C}$ inhibitor [33]. This is particularly the case for glycosylation. Rabbits add almost quantitatively sialic acid under the NANA form (N-acetylneuranumic acid) to protein $\mathrm{C}$ inhibitor [33], whereas goats are unable to sialylate completely antithrombin III and about half of the sialic acid is under the NGNA form (N-glycosylneuranumic acid) [37]. The latter form is not present in human proteins and its presence in recombinant proteins could generate the formation of antibodies by patients. The proteins lacking sialic acid generally have an excess of terminal mannose which favours their rapid elimination from the blood. Interestingly, the protein C inhibitor [33] and a coagulation blood factor (unpublished data) secreted in rabbit milk did not contain fucose. This suggests that fucosylation is poorly active in the rabbit mammary gland. The property is expected to allow the synthesis of non fucosylated monoclonal antibodies in milk. This point is of importance since the absence of fucose on antibodies is the major factor allowing antibodies to induce the ADCC activation of T lymphocytes [38].

It is worth noting that very complex recombinant proteins are secreted in milk in a highly active form. This is the case for several antibodies which are well-shaped and glycosylated but also for collagen and fibrinogen which are formed of several subunits. Interestingly, human extracellular superoxide dismutase which must contain one copper ion per monomer was secreted in an active form from rabbit milk at concentrations as high as $1-3 \mathrm{mg} \cdot \mathrm{mL}^{-1}$ [39]. Some recombinant blood factors found in milk were almost similar to their native counterparts as judged by the elimination of the pro- and pre-peptides, $\gamma$ carboxylation, O-and N- glycosylations, $\beta$ - hydroxylation and their cleavage into subunits.

Purification of recombinant proteins from blood is difficult in some cases. This is due to the presence of very high amounts of milk proteins and to the fact that some recombinant proteins may be trapped within casein micelles or bound to milk lipids [40].

\section{DISCUSSION}

Transgenesis offers unprecedented possibilities to modify milk composition for different purposes. The recent technical progress to generate transgenic animals and to construct efficient recombinant genes makes the large scale use of transgenesis for the improvement of human and animal health more likely.

It should be noted that, although encouraging, the data reported in the review are still too preliminary to consider that milk containing antibacterial proteins will be some day incorporated into food or used to favour breeding. The efficiency of these molecules presently makes little doubt but their innocuousness for humans and animals remains to be proved. However, it must be kept in mind that a transgene has a chance to be disseminated in herds only if the new genetic trait is expected to bring enough profit. The success of genetically modified plants cannot be met so easily in the animal field.

The modification of milk composition to reduce its content in allergenic proteins or lactose may be attractive for some consumers. Projects as ambitious as the replacement of cow casein genes by human casein genes are presently feasible.

The secretion of nutriceuticals such as omega-3 lipids is another possibility. A number of other non-proteinous molecules could be secreted in milk via transgenesis. The progress in this field is expected to be slow since it requires a relatively heavy 
investment and a relatively long time to generate and since it multiplies transgenic founders as well as evaluates the benefit and the innocuousness of the new products.

The use of milk as a source of pharmaceuticals appears close to reaching a symbolic step. Two human proteins, antithrombin III and protein $\mathrm{C}$ inhibitor are approved by EMEA (European Medicament Evaluation Agency) and in late clinical phase III respectively. One of these proteins or both might soon be on the market. The delay between the first demonstration that milk may be a valuable source of pharmaceutical proteins in 1986 and the moment in which one of the proteins will be provided to patients may appear long. It should be kept in mind that 10-15 years are needed to validate new drugs obtained by chemical synthesis. The situation is more complex with proteins. New methods had to be defined and improved to implement transgenic animals. Moreover, proteins are very complex molecules and their structure must be examined with special care to make sure that they are similar or very close to their native counterparts. In addition, specific guidelines have had to be discussed and written to define safe conditions for the preparation of pharmaceutical proteins from animals. The relatively slow progress cannot thus be considered as a failure. This long delay did not allow several start-ups to find long-term investment to survive.

The use of milk as a source of pharmaceutical proteins is thus likely but its real impact depends on the progress of the other systems. Indeed, efforts are being made to enable bacteria and yeast to glycosylate proteins as animal cells do [30]. Transgenic plants containing pharmaceutical proteins in their leaves or their seeds are attractive since the production cost of the proteins would be particularly low. Improvement of the glycosylation machinery in this system is underway [41]. However, purification of the proteins may prove problematic in some cases due to contamination by molecules like polyphenols. The large scale culture in fields of producing plants may raise real human health problems in some cases [42].

Possible alternatives are to use microalgae or duck weed. Each of them can produce large amounts of biomass in confined areas [43].

The use of cultured plant cells is another possibility [44].

The use of cultured animal cells and particularly of $\mathrm{CHO}$ cells (Chinese hamster ovary) is a reality. The efficiency of these techniques is continually improving since conditions of culture are better and better controlled. Cells produce higher and higher quantities of proteins and cells are being engineered to optimise glycosylation and other posttranslational modifications $[32,45]$. Yet, CHO cells have limited production capacity and the implementation of new $\mathrm{CHO}$ fermentors remains costly, slow and poorly flexible [45].

The milk system can be improved by designing new vectors having a higher reliability to produce high quantities of proteins. Animals are also being engineered to optimise protein cleavage, glycosylation and $\gamma$-carboxylation.

Other animal systems have been envisaged. Urine and pig seminal plasma might be a valuable source of recombinant proteins [46]. However, the advantage of seminal plasma over the milk system appears limited to intellectual property.

Silk gland from worms has been proven to be a possible unique source of various silks. Interestingly, a recent work showed than human proteins can be secreted with silk. They are bound to one of the silk proteins and they can be released in water by a mild treatment [47].

Egg white has appeared as a system potentially as attractive as milk to prepare pharmaceutical proteins. For years, due to the inefficiency of available methods to generate transgenic chickens, no 
angible success was achieved. Recent studies have shown that ES and PGG cell lines can be implemented to generate transgenic birds [3-5] and a monoclonal antibody was produced in egg whites [3]. These experimenters incline to consider that egg white is now becoming a source of pharmaceutical proteins.

An interesting point is worth being mentioned. In a recent study, it was shown that adenoviral vectors injected directly in the goat mammary gland through teats made transient production of high amounts of human growth hormone possible [48]. This system is somewhat laborious and may raise biosafety problems. It avoids the generation of transgenic animals and it may be appropriate for obtaining proteins which are toxic for animals.

The number of systems to produce recombinant proteins is slowly increasing. None of these systems has all the advantages. The different systems should be chosen on a case by case basis according to the protein to be produced. Milk will likely be one of the major systems. Whatever happens, it is important to note that about 500 monoclonal antibodies are under preclinical or clinical studies and that 50-100 other recombinant proteins should be produced in the coming years or decades (50). Some experts consider that the demand is increasing and that all the available systems might be required to meet the demand in one decade hence [32].

\section{ACKNOWLEDGEMENTS}

The authors wish to thank Mrs Annie Paglino for the preparation of the manuscript.

\section{REFERENCES}

[1] Houdebine LM, Use of transgenic animals to improve human and health and animal production. Reprod Dom Anim 2005, 40: 269-281.
[2] Kuroiwa Y, Kasinathan P, Matsushita H, Sathiyaselan J, Sullivan EJ, Kakitani M, Tomizuka K, Ishida I, Robl JM. Sequential targeting of the genes encoding immunoglobulin-micro and prion protein in cattle. Nature Genet 2004, 36: 671-672.

[3] Zhu L, et al. Production of human monoclonal antibody in eggs of chimeric chickens. Nat Biotechnol 2005, 23: 1159-1169.

[4] Van de Lavoir MC, Diamond JH, Leighton PA, Mather-Love C, Heyer BS, Bradshaw R, Kerchner A, Hooi LT, Gessaro TM, Swanberg SE, Delany ME, Etches RJ. Germline transmission of genetically modified primordial germ cells. Nature 2006, 441: 766-769.

[5] Han JY, Park TS, Lim JM. Chicken pluripotent cells and transgenesis. Transgenic Res 2006, 15: 118.

[6] Whitelaw CBA. Transgenic livestock made easy. Trends Biotechnol 2004, 22: 157-160.

[7] Whitelaw CB, Radcliffe PA, Ritchie WA, Carlisle A, Ellard FM, Pena RN, Rowe J, Clark AJ, King TJ, Mitrophanous KA., Efficient generation of transgenic pigs using equine infectious anaemia virus (EIAV) derived vector. FEBS Letters 2004, 571: 233-236.

[8] Houdebine L, Attal J, Vilotte JL. Vector design for transgene expression. In: Pinkert CA (Ed), Transgenic animal technology, 2nd ed, Academic Press, 2002, p 419-458.

[9] Giraldo P, Rival-Gervier S, Houdebine LM, Montoliu L. The potential benefits of insulators on heterologous constructs in transgenic animals. Transgenic Res 2003, 12: 751-755.

[10] De Laat W, Grosveld F. Spatial organization of gene expression: the active chromatin hub. Chromosome Res 2003, 11: 447-459.

[11] Rival-Gervier S, Viglietta C, Maeder C, Attal J, Houdebine LM. Position-independent and tissue-specific expression of porcine whey acidic protein gene from a bacterial artificial chromosome in transgenic mice. Mol Reprod Dev 2002, 63: 161-167.

[12] Zhang XF, Wu GX, Chen JQ, Zhang AM, Liu SG, Jiao BH, Cheng GX. Transfer of an expression YAC into goat fetal fibroblasts by cell fusionfor mammary gland bioreactor. Biochim Biophys Res Comm 2005, 333: 58-63.

[13] Gong GC, Day YP, Zhu HB, Tang B, Zhao YF, Wang LL, Waang HP, Liu Y, Li R, Hammerström L, LI N. Expression of Lewis a antigen in the milk of cloned 
calves transferred with human alpha-1,3/4fucosyltransferase gene. Transgenic Res 2006, 15: 122.

[14] Novina CD, Sharp PA. The RNAi revolution. Nature 2004, 430: 161-164.

[15] Mittal V. Improving the efficiency of RNA interference in mammals. Nat Rev Genet 2004, 5: 355-365.

[16] Zeng Y, Yi R, Cullen BR. MicroRNAs and small interfering RNAs can inhibit mRNA expression by similar mechanisms. Proc Natl Acad Sci USA 2003, 100: 9779-9784.

[17] Bleck GT, White BR, Miller DJ, Wheeler MB. Production of bovine alpha-lactalbumin in the milk of transgenic pigs. J Anim Sci 1998, 76: 3072-3078

[18] Brophy B, Smolenski G, Wheeler T, Wells D, L'Huillier P, Laible G. Cloned transgenic cattle produce milk with higher levels of beta-casein and kappa-casein. Nat Biotechnol 2003, 21: 157-162.

[19] Brophy B, Smolenski G, Wells DN, Wheeler TT, Laible G. Increased casien gene dosage and its implicatyion for the composition of milk. Transgenic Res 2006, 15: 123.

[20] Vilotte JL. Lowering the milk lactose content in vivo: potential interests, strategies and physiological consequences. Reprod Nutr Dev 2002, 42: 127-132.

[21] Jost B, Vilotte JL, Duluc I, Rodeau JL, Freund JN. Production of low-lactose milk by ectopic expression of intestinal lactase in the mouse mammary gland. Nat Biotechnol 1999, 17: 160-164.

[22] Reh WA, Maga EA, Collette NMB, Moye A, Conrad-Brink JS, Taylor SJ, DePeters EJ, Oppenheim S, Rowe JD, BonDurant RH, Anderson GB, Murray JD. Hot topics:using a stearoyl-CoA desaturase transgene to alter milk fatty acid composition. J Dairy Sci 2004, 87: 3510-3514

[23] Kao B, Moromoto K, Depeters E, Lewis K, Medrano J, Van Eenennaam. Endogenous production of omega-3 fatty acids in milk Transgenic Res 2006, 15: 117.

[24] Castilla J, Pintado B, Sola I, SanchezMorgado JM, Enjuanes L. Engineering passive immunity in transgenic mice secreting virus- neutralizing antibodies in milk. Nat Biotechnol 1998, 16: 349-354.

[25] Kolb AF, Pew L, Webster J, Penman S, Whitelaw CB, Siddell SG. Virus neutralizing monoclonal antibody expressed in milk of transgenic mice provides full protection against virus- induced encephalitis. J Virol 2001, 75: 2803-289.
[26] Wall RJ, Powell AM, Paape MJ, Kerr DE, Bannerman DD, Pursel VG, Wells KD, Talbot N, Hawk HW. Genetically enhanced cows resist intramammary Staphylococcus aureus infection. Nat Biotechnol 2005, 23: 445-451.

[27] Maga E. Properties of milk from human lysozyme transgenic goats. Transgenic Res 2006, 15: 117.

[28] Thomassen EA, van Veen HA, van Berkel $\mathrm{PH}$, Nuijens JH, Abrahams JP. The protein structure of recombinant lactoferrin produced in milk of transgenic cows closely matches the structure of human milkderived lactoferrin. Transgenic Res 2005, 14 397-405.

[29] Baneyx F, Mujacic M. Recombinant protein folding and misfolding in Escherichia coli. Nat Biotechnol 2004, 22: 1399-13408.

[30] Hamilton SR, Bobrowicz P, Bobrowicz B, Davidson RC, Li H, Mitchell T, Nett JH, Rausch S, Stadheim TA, Wischnewski $\mathrm{H}$ Wildt S, Gerngross TU. Production of complex human glycoproteins in yeast. Science 2003, 301: 1244-1246.

[31] Massoud M, Bischoff R, Dalemans W, Pointu H, Attal J, Schultz H, Clesse D, Stinnakre MG, Pavirani A, Houdebine LM. Expression of active recombinant human alpha 1-antitrypsin in transgenic rabbits. J Biotechnol 1991, 18: 193-203.

[32] Houdebine LM. Antibody manufacture in transgenic animals and comparisons with other systems. Curr Opin Biotechnol 2002, 13: 625-629.

[33] Koles K, van Berkel PH, Pieper FR, Nuijens JH, Mannesse ML, Vliegenthart JF, Kamerling JP. N- and O-glycans of recombinant human $\mathrm{C} 1$ inhibitor expressed in the milk of transgenic rabbits. Glycobiology 2004, 14: 51-64.

[34] Soler E, Le Saux A, Guinut F, Passet B, Cohen R, Merle C, Charpilienne A, Fourgeux C, Sorel V, Piriou A, Schwartz-Cornil I, Cohen J, Houdebine LM. Production of two vaccinating recombinant rotavirus proteins in the milk of transgenic rabbits. Transgenic Res 2005, 14 833-844.

[35] Soler E, Le Saux A, Guinut F, Passet B, Cohen R, Merle C, Charpilienne A, Fourgeux C, Sorel V, Piriou A, Schwartz-Cornil I, Cohen J, Houdebine LM. Transgenic Animal Research, Conference V, Tahoe City, USA. Transgenic Res 2006, 15 : 120. 
[36] Lubon H. Transgenic animal bioreactors in biotechnology and production of blood proteins. Biotechnol Annu 1998, 4: 1-54.

[37] Edmunds T, Van Patten SM, Pollock J, Hanson E, Bernasconi R, Higgins E, Manavalan $\mathrm{P}$, Ziomek $\mathrm{C}$, Meade $\mathrm{H}$, McPherson J, Cole ES. Transgenically produced human antithrombin: strucutural and functional comparison to human plasma-derived antithrombin. Blood 2005, 91: 4561-4571.

[38] Shinkawa T, Nakamura K, Yamane N, ShojiHosaka E, Kanda Y, Sakurada M, Uchida K, Anazawa H, Satoh M, Yamasaki M, Hanai $\mathrm{N}$, Shitara K. The absence of fucose but not the presence of galactose or bisecting $\mathrm{N}$ acetylglucosamine of human IgG1 complextype oligosaccharides shows the critical role of enhancing antibody-dependent cellular cytotoxicity. J Biol Chem 2003, 278: 3466-3473.

[39] Stomqvist M, Houdebine LM, Andersson JO, Edlund A, Johansson T, Viglietta C, Puissant C, Hansson L. Recombinant human superoxide dismutase produced in milk of transgenic rabbits. Transgenic Res 1997, 6: 271-278.

[40] Stowers AW, Chen Lh LH, Zhang Y, Kennedy MC, Zou L, Lambert L, Rice TJ, Kaslow DC, Saul A, Long CA, Meade H, Miller LH. A recombinant vaccine expressed in the milk of transgenic mice protects Aotus monkeys from a lethal challenge with Plasmodium falciparum. Proc Natl Acad Sci USA 2002, 99: 339-344.
[41] Gomord V, Chamberlain P, Jefferis R, Faye L. Biopharmaceutical production in plants: problems, solutions and opportunities. Trends Biotechnol 2005, 23: 559-565.

[42] Kirk DD, McIntosh K, Walmsley AM, Peterson RK. Risk analysis for plant-made vaccines. Transgenic Res 2005, 14: 449-462.

[43] Leon-Banares R, Gonzalez-Ballester D, Galvan A, Fernandez E. Transgenic microalgae as green cell-factories. Trends Biotechnol 2004, 22: 45-52.

[44] Hellwig S, Drossard J, Twyman RM, Fischer R. Plant cell cultures for the production of recombinant proteins. Nat Biotechnol 2004, 22: 1415-1422.

[45] Thiel KA. Biomanufacturing from bust to boom... to bubble? Nat Biotechnol 2004, 22: $1365-1372$.

[46] Birse D, Lacroix D, Dyck M, Pothier F, Sirard MA, Biotherapeutics from transgenic porcine sources: bioprocessing approaches and challenges. Bioprocessing J 2004, 4: $1-8$.

[47] Royer C, Jalabert A, Da Rocha M, Grenier AM, Mauchamp B, Couble P, Chavancy G. Biosynthesis and cocoon-export of a recombinant globular protein in transgenic silkworms. Transgenic Res 2005, 14: 463-472.

[48] Sanchez O, Toledo JR, Rodriguez MP, Castro FO. Adenoviral vector mediates high expression levels of human growth hormone in the milk of mice and goat. J Biotechnol 2004, 114: 89-97.

[49] Walsh G. Biopharmaceutical benchmark. Nat Biotechnol 2003, 21: 865-870.

To access this journal online: www.edpsciences.org/rnd 